
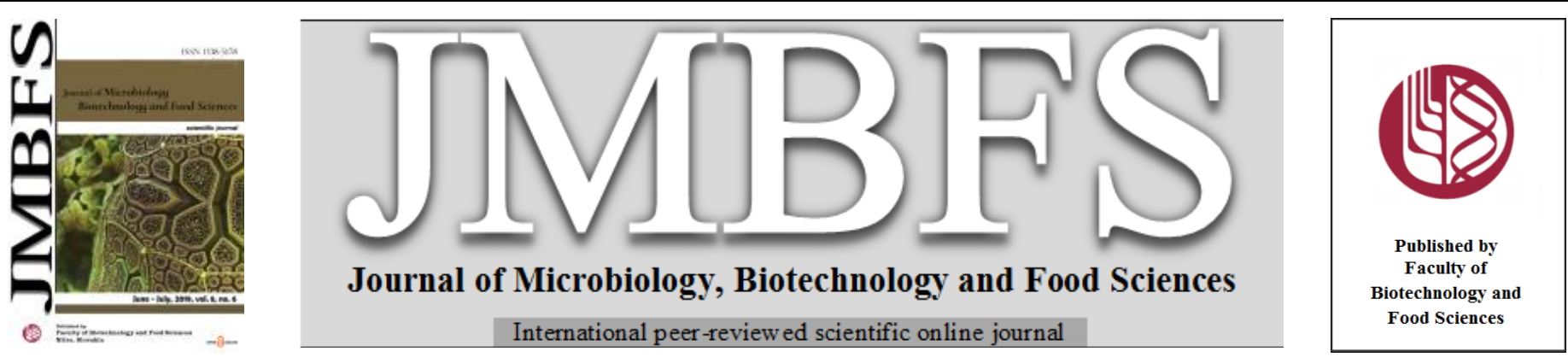

\title{
IMPACT OF BREAK IN COLD CHAIN ON THE TECHNOLOGICAL AND ORGANOLEPTIC QUALITIES OF ATLANTIC MACKEREL (SCOMBER SCOMBRUS) AND HORSE MACKEREL (TRACHURUS TRACHURUS) IN SOUTH BENIN
}

\section{Martinien Hospice Mahussi Assogba ${ }^{2}$, Chakirath Folakè Arikè Salifou ${ }^{1}$, Pamphile Tobada ${ }^{2}$, Abdou Karimou Aboudou , Aïssatou Bio Bakary ${ }^{1}$, Mahamadou Dahouda ${ }^{3}$, Antoine Chikou, Souä̈bou Farougou ${ }^{5}$, Issaka Youssao Abdou Karim ${ }^{1}$}

Address(es):

${ }^{1}$ Laboratory of Animal Biotechnology and Meat Technology, Department of Animal Production and Health, Polytechnic School of Abomey-Calavi, University of Abomey-Calavi, 01 BP:2009 Cotonou, Republic of Benin.

${ }^{2}$ Laboratory of Applied Biology Research, Polytechnic School of Abomey-Calavi, University of Abomey-Calavi, 01BP:2009 Cotonou, Benin.

${ }^{3}$ Department of Animal Production, Faculty of Agronomic Sciences, University of Abomey-Calavi, 01 BP:526, Cotonou, Republic of Benin.

${ }^{4}$ Laboratory of Hydrobiology and Aquaculture, Faculty of Agronomic Sciences, University of Abomey-Calavi, 01 BP:526 Cotonou, Benin.

${ }^{5}$ Research Unit in Biotechnology of Animal Production and Health, Department of Animal Production and Health, Polytechnic School of Abomey-Calavi, University of Abomey-Calavi, 01 BP:2009 Cotonou, Republic of Benin.

*Corresponding author: assogbahospice@ gmail.com

doi: 10.15414/jmbfs.2019.8.6.1242-1248

\section{ARTICLE INFO}

Received 5.9. 2018

Revised 30. 12. 2018

Accepted 15. 1.2019

Published 1. 6. 2019

Regular article OPEN $\partial_{\text {ACCESS }}$

\section{ABSTRACT}

Horse mackerel and Atlantic mackerel are species often imported and sold in Benin in frozen form. This study aimed to evaluate the impact of the break in cold chain on the technological and organoleptic qualities of these fish in south Benin. Thus, it was carried out from June to December 2016 in the Department of Atlantic and Littoral. For the study, fish samples (120 Atlantic mackerel and 120 Horse mackerel) were taken for laboratory analyzes. It appears that the weight of the whole fish, the weight of the eviscerated fish and the weight of the remains were significantly higher for the breaks of 6 hours than for the breaks of 3 hours and 12 hours. The fillet weight of fish at 6 hours (140.4g) of cold break was significantly higher than that at 3 hours $(112 \mathrm{~g})$ of cold break. No influence of break in cold chain was observed on the yield, fillet yield, water content and $\mathrm{pH}$. Whatever the break duration, the different weights recorded were significantly higher in Horse mackerel than in Atlantic mackerel. The various weights recorded in Atlantic mackerel with 3 and 12 hours of break were higher than those recorded with 6 hours of break. The red index was higher for the 6 hours of break than for the 12 hours of break $(\mathrm{P}<0.05)$. The break duration had significantly influenced the freshness state of skin, eye, back muscle, abdominal wall, spine and organ color $(\mathrm{P}<0.001)$. The break in the cold chain alters the technological and organoleptic quality of fish.

Keywords: Chain; break; cold; quality; processing; Technology

\section{INTRODUCTION}

Fish is the main animal protein source for the populations (Okpanachi et al., 2018). While Benin's population is growing $(10,000,000$ inhabitants in 2014), the cover of animal protein needs is in deficit. Facing this situation, in 2015, Benin imported 81,327 tons of frozen fish, dominated by Horse mackerel, Atlantic mackerel and Sardinella (FAO, 2017). Thus, in order to ensure the quality integrity of these fish, conservation by continuous cold is indispensable. The conservation methods used are freezing, refrigeration and ice preservation (Gandrota et al., 2012; Tolstorebrov et al., 2017; Lanlan et al., 2017). These methods preserve the freshness state, nutritional qualities and taste properties of fish and aim to extend their shelf life (Nalan and Pilar, 2015; Varghese and Mathew, 2016)

However, when fish are poorly preserved or undergo break in the cold chain, they are likely to favor pathogenic micro-organisms development or toxins production (ANSES, 2010; Simoes, 2016) and provoke inconveniences, in particular to the food industry sector. The prolonged storage of cold-stored fish can degrade cell walls, cause weight loss and promote proteins denaturation. The freshness state, vitamins and nutritional value of these fish are also altered. These various deteriorations are the cause of three major mechanisms: cellular autolysis, microbial growth and oxidative reactions (Ghaly et al., 2010; Sharifian $\boldsymbol{e t}$ al., 2014). Thus, the quality of imported frozen sea-fish (Scomber scombrus, Trachurus trachurus), which already undergo relatively long storage before being discharged into local markets, is questioned (Abubakar and Uzairu, 2015; Kabamba, 2016). This depends on the storage temperature and storage duration as well as on the freezing technique used (Popelka $\boldsymbol{e t}$ al., 2012). In addition to the dubious quality of these fish, in Benin, the surveys carried out by Bocodaho (2015) and Gnimavo (2015) on frozen fish imported in Benin revealed that the storage temperature is not constant during storage in fish-shops of Cotonou (98\%) and Abomey Calavi (78\%). This break in the cold chain is provoked for several reasons including the power cut due to generators failure and the consumer electricity high price. According to Moons (2016), any liquid having undergone this break in the cold chain is likely to present risks to the consumer health. In general, changes that occur during the storage limit these fish use as a raw material for the processing sector or as a food for the consumer (Bou m'handi et al., 2015).

In order to improve these fish quality, several studies were carried out on their microbiological quality during smoking (Degnon et al., 2012, 2013, Chabi et al. 2014; Kpodekon et al., 2014) and preservation (Wabi, 2010). Apart from the microbiological quality, no study was carried out on the impact of break in the cold chain on the technological and organoleptic qualities of frozen fish, despite the frequent power cut registered In Benin. The objective of the study is to evaluate the impact of break in the cold chain on the technological and organoleptic qualities of Atlantic mackerel (Scomber scombrus) and Horse mackerel (Trachurus trachurus) in south Benin. These two fish species were chosen because of their high frequency in households' consumption in south Benin.

\section{MATERIAL AND METHODS}

\section{Study area}

The data collection on the impact of break in the cold chain on the technologica and organoleptic qualities of Atlantic mackerel (Scomber scombrus) and Horse mackerel (Trachurus trachurus) in south Benin was carried out from June to December 2016 in the Township of Abomey Calavi. 
This Township is located at 12 meters of altitude between $6^{\circ} 26^{\prime}$ North latitude and $2^{\circ} 21^{\prime}$ East longitude. It is in the Atlantic Department, South of Benin and bounded to the North by the Township of Zè, to the South by the Atlantic Ocean, to the East by the Township of Sô-Ava and Cotonou, and to the West by the Township of Tori-Bossito and Ouidah. The climate is of the subequatorial type characterized by two rainy seasons and two dry seasons. The Township has two bodies of water, Nokoué Lake and Cotonou Lagoon, a sea front juxtaposed to Cotonou Lagoon, marshes, streams and swamps. These bodies of water offer the Township a very lively artisanal fishing activity. The township has also severa local markets (Kpota, Glodjigbé, Akassato, Zinvié and Zè). The Kpota market has an embankment where caught fish in the Nokoué Lake are regularly sold. In this market fish are marketed whole or processed. Fish processing is of artisana type. Once the cold chain break tests performed, the data on the technological and organoleptic parameters were collected and analyzed at the Laboratory of Animal Biotechnology and Meat Technology of the Department of Anima Production and Health of the Polytechnic School of Abomey-Calavi of the University of Abomey-Calavi.

\section{Experimental procedure and samples}

A total of 120 Atlantic mackerel (Scomber scombrus) and 120 Horse mackerel (Trachurus trachurus) were sampled for the assessment of the effect of break in cold chain on these fish quality at the laboratory. These fish were sampled at the Food Products Distribution Common Agency in Cotonou, at the supply place of wholesalers and retailers. They were then transported to the laboratory in a coole at $4^{\circ} \mathrm{C}$ in accordance with the ISO 7218: 2007 standard. Two preservation methods were tested: freezing $\left(-18^{\circ} \mathrm{C}\right)$ and refrigeration $\left(+4^{\circ} \mathrm{C}\right)$.

Several fish batches were formed: the batch1: intended for refrigeration didn't undergo power cut during the experimentation, it is the control batch1; the batch 2: intended for freezing didn't undergo power cut during the experimentation, it is the control batch 2; The batches 3,4 and 5: intended for refrigeration, underwent respectively power cuts of 3 hours, 6 hours and 12 hours per day for 3 days each; The batches 6, 7 and 8: intended for freezing, respectively underwent power cuts of 3 hours, 6 hours and 12 hours per day for 3 days each. For each batch, according to the preservation mode and to the power cuts, ten (10) fish were considered and this by species. The control batches that didn't experience power cut, received each 10 fish per species for each preservation mode.

The technological parameters measures were taken. The $\mathrm{pH}$ at $1 \mathrm{~h}, 3 \mathrm{~h}$ and $6 \mathrm{~h}$ after each break in the cold chain were taken over 3 days and this by batch. For the $3 \mathrm{~h}$ of break, only $\mathrm{pH}$ at $\mathrm{h}$ and $3 \mathrm{~h}$ were taken.

The water content of fish fillets was determined according to the Codex Stan 167-1989 standard. The fish yield (eviscerated fish weight*100/ total weight of whole fish) and filleting yield (fillet weight*100/total weight) were calculated Concerning the organoleptic parameters, the fish freshness state was assessed according to the regulation $\mathbf{7 9 0 / 2 0 0 5 / E C}$, the color was taken according to Mathis (2003) using a colorimeter (Konica Minolta CR-400 INC) where the red index $\left(a^{*}\right)$, the yellow index $\left(b^{*}\right)$, the lightness $\left(L^{*}\right)$ were measured and the chroma was calculated by the following formula: $\mathrm{C}^{*}=\left(\mathrm{a}^{* 2}+\mathrm{b}^{* 2}\right)^{1 / 2}$

\section{Statistical analysis}

The Proc means procedure of SAS (2013) was used to calculate the averages of the different technological and organoleptic variables. The General Linear Model (GLM) procedure was used for the variance analysis and the variation sources taken into account were fish species, power cut techniques, power cut duration, and the interaction between species and power cuts. The F test was used to determine the significance of each effect of the variance analysis model and averages were calculated and compared by the student $t$ test.

\section{RESULTS}

\section{Technological characteristics of fish}

Effect of species, preservation technique and break duration on the technological characteristics of fish

The whole fish weight and the various organs/parts weight (eviscerated fish, fillets, viscera) of Atlantic mackerel were significantly higher than those of Horse mackerel $(\mathrm{P}<0.001)$. By contrast, Horse mackerel showed a higher yield than Atlantic mackerel $(93.75 \%$ vs $92.42 \%, \mathrm{P}<0.001)$ (Table 1). The whole fish weight, eviscerated fish weight, net weight, viscera weight and the remains were respectively $405.99 \mathrm{~g}, 373.63 \mathrm{~g}, 183.84 \mathrm{~g}, 30.35 \mathrm{~g}$ and $222.1 \mathrm{~g}$ in Atlantic mackere against $178.38 \mathrm{~g}, 167.56 \mathrm{~g}, 73.13 \mathrm{~g}, 10.82 \mathrm{~g}$ and $105.25 \mathrm{~g}$ in Horse mackerel. The fillet yield was significantly higher $(\mathrm{P}<0.05)$ in Atlantic mackerel $(45.85 \%)$ than in Horse mackerel $(41.17 \%)$ (Table 1$)$. The water content was significantly higher $(\mathrm{P}<0.01)$ in Horse mackerel $(71.38 \%)$ than in Atlantic mackerel $(65.55 \%)$. This water content differs from one species to another $(\mathrm{P}<0.01)$ (Table 1). The
$\mathrm{pH}$ values in Atlantic mackerel ranged from 6.13 to 6.24 and those in Horse mackerel from 6.27 to 6.3 . The $\mathrm{pH}$ of Atlantic mackerel decreased from $3 \mathrm{~h}$ to $6 \mathrm{~h}$ of break in cold chain (6.24 to 6.13). By contrast, the one of Horse mackerel from $1 \mathrm{~h}$ to $3 \mathrm{~h}$ of break $(6.3$ to 6,27$)$ and increased at $6 \mathrm{~h}$ of break $(6,29)$. No influence of the preservation technique was observed on the whole fish weight, eviscerated fish weight, viscera weight, remains, and water content. On the contrary, the refrigerated experimental batch showed the best fish yield and the lowest fillet yield. The different $\mathrm{pH}$ values were influenced by the preservation technique (freezing and refrigeration). The highest $\mathrm{pH}$ values were found in frozen fish and the lowest in refrigerated fish. Apart from $\mathrm{pH} 6$, which was higher $(\mathrm{P}<0.05)$ in the refrigerated control batch than in the refrigerated experimental batch, no difference was found between $\mathrm{pH}$ values in the same preservation technique (Table 1).

The break duration influenced significantly the different weights (whole fish, eviscerated fish, viscera, fillet and the remains). Thus, the whole fish weight, the eviscerated fish weight and the remains weight were significantly higher $(\mathrm{P}<0.05)$ for the 6 hours of break than for the 3 hours and 12 hours of breaks. The viscera weight was significantly higher for fish with 6 hours and 12 hours of break than with 3 hours of break. The fillet weight at 6 hours $(140.40 \mathrm{~g})$ of preservation break was significantly higher than the weight at 3 hours $(112 \mathrm{~g})$ of preservation break. By contrast, no influence of the break in the cold chain was observed on fish yield, fillet yield, water content and $\mathrm{pH}$ (Table 2).

\section{Organoleptic characteristics of fish}

\section{Variation of color according to the day, the species and the break duration}

The color variability between day, species, and break duration is shown in the Table 3. The lightness, the yellow index and the red index didn't vary with the break day. On the contrary, the chroma was higher on the days 2 and 3 than on the day $1(\mathrm{P}<0.05)$.

The red index of Atlantic mackerel (Scomber scombrus) was higher $(\mathrm{P}<0.01)$ than that of Horse mackerel (Trachurus trachurus). The same trend was obtained for the yellow index and the chroma.

The lightness, yellow index and chroma didn't vary with the break in cold chain duration. However, the red index was higher $(\mathrm{P}<0.05)$ for the 6 hours of break than for the 12 hours of break.

Whatever the day, the lightness, red index, yellow index and chroma didn't significantly vary from one species to another. The same trends were obtained for these parameters according to the sex on the day 1 and to the break duration on the day 3 (Table 4). By contrast, fish were lighter for 3 hours of breaks than for 12 hours of breaks on the day 1 . The red index, yellow index, and chroma didn't significantly vary with the break duration on the day 1 . On the day 2, the lightness and red index didn't vary with sex, while the yellow index and chroma were significantly higher in the female than in the male. On the same day 2, the lightness, the red index and the chroma didn't significantly vary by the break duration whereas the yellow index was lower for the 3 hours of breaks than for the breaks of 6 hours and 12 hours. On the day 3, females were lighter than males while the red index, yellow index, and chroma were higher in males than in females (Table 4).

\section{Assessment of the freshness state of fish}

The preservation technique had no influence on the freshness state of the skin, the eye, the gills and the abdominal cavity. By contrast, it highly influenced $(\mathrm{P}<0.001)$ the freshness state of the back muscle, abdominal wall, spine and the organs color. The back muscle of frozen fish and of refrigerated control batch fish was firm, rigid and elastic, whereas the refrigerated experimental batch fish had a dorsal muscle that decreased in elasticity. The abdominal wall was intact in the frozen fish (control and experimental batches) and in the refrigerated control batch fish, whereas it was less soft in the refrigerated experimental batch fish (Table 5).

The break duration had no effect on the state of gills and abdominal cavity but it has significantly influenced the freshness state of the skin, eye, back muscle abdominal wall, spine and of the organ color $(\mathrm{P}<0.001)$ (Table 6). With the breaks of 3 hours and 12 hours, the fish skin was light without luster with slightly unclear mucus and odor neither seaweed nor bad, while with a break of 6 hours, this skin was light, shimmering without discoloration with aqueous and transparent mucous and a seaweed odor. For the breaks of 3 hours and 6 hours, the dorsal muscle was firm, rigid and elastic and became less elastic when the rupture lasted 12 hours. The abdominal wall was intact for the breaks of 3 hours and 12 hours but less soft for the break of 6 hours. The spine was slightly pink with adhesions for the breaks of 6 hours and 12 hours while it was colorless and broke down instead of being removed for the breaks of 3 hours. The organs color was red masts for the breaks of 6 hours but bright red for the breaks of 3 hours and 12 hours. 
Table 1 Effect of the species and preservation technique on the technological characteristics of fish

\begin{tabular}{|c|c|c|c|c|c|c|c|c|c|c|c|c|c|c|}
\hline \multirow{3}{*}{ Variation Source } & \multicolumn{4}{|c|}{ Species } & \multicolumn{8}{|c|}{ Techniques } & \multirow{2}{*}{\multicolumn{2}{|c|}{ Significance test }} \\
\hline & \multicolumn{2}{|c|}{ Scomber scombrus } & \multicolumn{2}{|c|}{$\begin{array}{l}\text { Trachurus } \\
\text { trachurus }\end{array}$} & \multicolumn{2}{|c|}{ TBF } & \multicolumn{2}{|c|}{ CBF } & \multicolumn{2}{|c|}{ CBR } & \multicolumn{2}{|c|}{ TBR } & & \\
\hline & Mean & SD & Mean & SD & Mean & SD & Mean & SD & Mean & SD & Mean & SD & Species & Techniques \\
\hline Whole fish weight (g) & 405.99 & 104.37 & 178.38 & 45.5 & $304.5 \mathrm{a}$ & 60.70 & $277.2 \mathrm{a}$ & 74.70 & $285.3 a$ & 145.30 & $299.7 \mathrm{a}$ & 157.8 & $* * *$ & NS \\
\hline $\begin{array}{l}\text { Eviscerated fish weight } \\
\text { (g) }\end{array}$ & 375.63 & 98.42 & 167.56 & 44.64 & $279.9 \mathrm{a}$ & 48.40 & $255.1 \mathrm{a}$ & 68.50 & $264.2 \mathrm{a}$ & 133.50 & $280.7 \mathrm{a}$ & 147.4 & $* * *$ & NS \\
\hline Fillets weight (g) & 183.84 & 40.85 & 73.13 & 18.12 & $133.1 \mathrm{a}$ & 34.60 & $125.3 \mathrm{a}$ & 29.20 & $130.8 \mathrm{a}$ & 69.40 & $125.9 \mathrm{a}$ & 69.5 & $* * *$ & NS \\
\hline Viscera weight $(\mathrm{g})$ & 30.35 & 9.19 & 10.82 & 2.15 & $24.6 \mathrm{a}$ & 14.24 & $22.05 \mathrm{a}$ & 12.92 & $21.12 \mathrm{a}$ & 12.45 & $18.97 \mathrm{a}$ & 10.9 & $* * *$ & NS \\
\hline Remains (g) & 222.1 & 69.8 & 105.25 & 29.78 & $171.4 \mathrm{a}$ & 31.8 & $151.9 \mathrm{a}$ & 50.4 & $154.5 \mathrm{a}$ & 80.1 & $173.7 \mathrm{a}$ & 90.4 & $* * *$ & NS \\
\hline Fish yield (\%) & 92.42 & 1.9 & 93.75 & 1.29 & $92.36 \mathrm{~b}$ & 3.44 & $92.23 b$ & 3.63 & $92.78 b$ & 1.28 & $93.72 \mathrm{a}$ & 0.88 & $* * *$ & $* * *$ \\
\hline Fillets yield & 45.85 & 5.03 & 41.17 & 4.39 & $43.45 \mathrm{ab}$ & 5.06 & $46.18 \mathrm{ab}$ & 7.18 & $45.1 \mathrm{a}$ & 5.47 & $41.41 \mathrm{~b}$ & 3.94 & $*$ & $* *$ \\
\hline Water content $(\%)$ & 65.55 & 6.45 & 71.38 & 10.86 & $67.67 \mathrm{a}$ & 14.28 & $72 \mathrm{a}$ & 13.56 & $70.2 \mathrm{a}$ & 5.59 & $66.2 \mathrm{a}$ & 10.23 & $* *$ & NS \\
\hline pH1 & 6.24 & 0.13 & 6.3 & 0.1 & $6.45 \mathrm{a}$ & 0.12 & $6.34 \mathrm{ab}$ & 0.12 & $6.26 \mathrm{~b}$ & 0.12 & $6.23 \mathrm{~b}$ & 0.07 & NS & $* * *$ \\
\hline pH3 & 6.24 & 0.14 & 6.27 & 0.11 & $6.45 \mathrm{a}$ & 0.16 & $6.54 \mathrm{a}$ & 0.18 & $6.22 b$ & 0.07 & $6.21 \mathrm{~b}$ & 0.08 & NS & $* *$ \\
\hline pH6 & 6.13 & 0.19 & 6.29 & 0.15 & $6.39 \mathrm{a}$ & 0.06 & $6.45 \mathrm{a}$ & 0.08 & $6.2 \mathrm{~b}$ & 0.11 & $6.04 c$ & 0.14 & NS & $* *$ \\
\hline
\end{tabular}

TBF : Tested Batch Freezing ; CBF : Control Batch Freezing ; CBR : Control Batch Refrigeration ; TBR : Tested Batch refrigeration ; SD : Standard Deviation ; $p H$ : Hydrogen potential. NS: $\mathrm{P}>0.05 ; *: \mathrm{P}<0.05 ; * *: \mathrm{P}<0.01$; ***: $\mathrm{P}<0.001$; The averages of the same line followed by different letters differ significantly at the threshold of $5 \%$;

Table 2 Effect of cold chain break on the technological characteristics of fish

\begin{tabular}{|c|c|c|c|c|c|c|c|}
\hline \multirow{3}{*}{ Variation source } & \multicolumn{6}{|c|}{ Break } & \multirow{3}{*}{ Significance test } \\
\hline & \multicolumn{2}{|c|}{ 3h } & \multicolumn{2}{|c|}{$6 \mathrm{~h}$} & \multicolumn{2}{|c|}{$12 \mathrm{~h}$} & \\
\hline & Mean & SD & Mean & SD & Mean & SD & \\
\hline Whole fish weight (g) & $264 \mathrm{~b}$ & 102 & $341.7 \mathrm{a}$ & 197.2 & $295.7 b$ & 121.4 & $*$ \\
\hline Eviscerated fish weight (g) & $247.7 \mathrm{~b}$ & 94.5 & $318.4 \mathrm{a}$ & 184.8 & $275.5 b$ & 111.8 & $*$ \\
\hline Fillets weight (g) & $112 \mathrm{~b}$ & 53.4 & $140.4 \mathrm{a}$ & 82.8 & $128.9 \mathrm{ab}$ & 56.3 & * \\
\hline Viscera weight (g) & $16.26 \mathrm{~b}$ & 9.52 & $23.29 \mathrm{a}$ & 13.9 & $20.17 \mathrm{a}$ & 10.44 & $*$ \\
\hline Remains (g) & $152.0 \mathrm{~b}$ & 51.0 & $201.3 \mathrm{a}$ & 116.4 & $166.7 \mathrm{~b}$ & 66.8 & $* * *$ \\
\hline Fish yield (\%) & $94.03 \mathrm{a}$ & 1.56 & $93.11 \mathrm{a}$ & 1.99 & $93.33 \mathrm{a}$ & 1.16 & NS \\
\hline Fillets yield & $41.11 \mathrm{a}$ & 4.96 & $40.86 a$ & 3.75 & $43.28 \mathrm{a}$ & 3.47 & NS \\
\hline Water content $(\%)$ & $67.5 \mathrm{a}$ & 15.4 & $64 \mathrm{a}$ & 7.72 & $67.83 \mathrm{a}$ & 7.93 & NS \\
\hline pH1 & $6.29 \mathrm{a}$ & 0.13 & $6.28 \mathrm{a}$ & 0.12 & $6.24 \mathrm{a}$ & 0.09 & NS \\
\hline pH3 & $6.25 \mathrm{a}$ & 0.11 & $6.19 \mathrm{a}$ & 0.11 & $6.24 \mathrm{a}$ & 0.08 & NS \\
\hline pH6 & - & - & $6.11 \mathrm{a}$ & 0.2 & $6.34 \mathrm{a}$ & 0.01 & NS \\
\hline
\end{tabular}

SD : Standard Deviation ; $p H:$ Hydrogen potential. NS: $\mathrm{P}>0.05 ; *: \mathrm{P}<0.05 ; * * *$ : $<<0.001 ;$ The averages of the same line followed by different letters differ significantly at the threshold of $5 \%$;

Table 3 Color variability between days, species and break duration

\begin{tabular}{|c|c|c|c|c|c|c|c|c|c|}
\hline \multirow{2}{*}{\multicolumn{2}{|c|}{ Variation source }} & \multicolumn{2}{|c|}{$\mathbf{L}^{*}$} & \multicolumn{2}{|c|}{$a^{*}$} & \multicolumn{2}{|c|}{$\mathbf{b}^{*}$} & \multicolumn{2}{|c|}{ Chroma } \\
\hline & & Mean & SD & Mean & SD & Mean & SD & Mean & SD \\
\hline \multirow{4}{*}{ Days } & $\mathbf{J 1}$ & $43.68 \mathrm{a}$ & 8.06 & $10.13 \mathrm{a}$ & 4.12 & $10.49 a$ & 7.22 & $140.60 \mathrm{~b}$ & 194.10 \\
\hline & $\mathbf{J} 2$ & $41.40 \mathrm{a}$ & 7.58 & $8.37 \mathrm{a}$ & 2.73 & $17.85 \mathrm{a}$ & 3.64 & $204.760 \mathrm{a}$ & 72.77 \\
\hline & $\mathbf{J 3}$ & $41.66 \mathrm{a}$ & 6.84 & $8.74 \mathrm{a}$ & 2.74 & $17.54 \mathrm{a}$ & 4.15 & $204.340 \mathrm{a}$ & 77.62 \\
\hline & Significance test & \multicolumn{2}{|c|}{ NS } & \multicolumn{2}{|c|}{ NS } & \multicolumn{2}{|c|}{ NS } & \multicolumn{2}{|c|}{$*$} \\
\hline \multirow{4}{*}{ Species } & Scomber scombrus & 41.95 & 9.09 & 10.22 & 3.67 & 16.35 & 6.98 & 216.9 & 163.00 \\
\hline & Trachurus trachurus & 42.59 & 5.59 & 7.94 & 2.5 & 14.24 & 5.21 & 149.6 & 74.09 \\
\hline & Significance test & \multicolumn{2}{|c|}{ NS } & \multicolumn{2}{|c|}{$* *$} & \multicolumn{2}{|c|}{$* *$} & \multicolumn{2}{|c|}{ ** } \\
\hline & 3 hours & $41.71 \mathrm{a}$ & 6.72 & $8.85 \mathrm{ab}$ & 3.45 & $14.66 \mathrm{a}$ & 6.73 & $174.40 \mathrm{a}$ & 97.90 \\
\hline \multirow{2}{*}{$\begin{array}{l}\text { Break } \\
\text { duration }\end{array}$} & 6 hours & $43.14 \mathrm{a}$ & 6.81 & $9.99 \mathrm{a}$ & 2.64 & $17.05 \mathrm{a}$ & 3.21 & $203.80 \mathrm{a}$ & 65.30 \\
\hline & 12 hours & $42.90 \mathrm{a}$ & 6.99 & $7.87 \mathrm{~b}$ & 2.68 & $15.69 \mathrm{a}$ & 7.34 & $183.70 \mathrm{a}$ & 109.60 \\
\hline
\end{tabular}

L*: lightness; $\mathrm{a}^{*}$ : red index; $\mathrm{b}^{*}$ : yellow index; J: Day; SD: Standard deviation; NS: P $>0.05$; *: $\mathrm{P}<0.05$; **: $\mathrm{P}<0.01$; the intra-class means of the same column followed by different letters differ significantly at the threshold of $5 \%$; 
Table 4 Color variability of fish fillets by species, sex and cold break duration per day

\begin{tabular}{|c|c|c|c|c|c|c|c|c|c|}
\hline \multirow{3}{*}{ Variation source } & & \multicolumn{8}{|l|}{ Day 1} \\
\hline & & \multicolumn{2}{|l|}{$\mathbf{L}^{*}$} & \multicolumn{2}{|l|}{$\mathbf{a}^{*}$} & \multicolumn{2}{|l|}{$\mathbf{b}^{*}$} & \multicolumn{2}{|c|}{ Chroma } \\
\hline & & Mean & SD & Mean & SD & Mean & SD & Mean & SD \\
\hline \multirow{3}{*}{ Species } & Scomber scombrus & 42.69 & 10 & 12.34 & 3.89 & 11.55 & 8.83 & 188.2 & 259.90 \\
\hline & Trachurus trachurus & 44.68 & 5.44 & 7.93 & 3.04 & 9.44 & 5.06 & 93.1 & 64.70 \\
\hline & Significance test & NS & & NS & & NS & & NS & \\
\hline \multirow{3}{*}{ Sexe } & Female & 43.51 & 17.25 & 6.57 & 4.06 & 12.74 & 17.94 & 251 & 557.0 \\
\hline & Male & 44.88 & 7.35 & 10.23 & 4 & 7.55 & 3.24 & 93.9 & 62.10 \\
\hline & Significance test & NS & & NS & & NS & & NS & \\
\hline \multirow{4}{*}{ Break duration } & 3 hours & $46.53 \mathrm{ab}$ & 6.23 & $10.2 \mathrm{a}$ & 4.88 & $7.42 \mathrm{a}$ & 3.01 & $94.7 \mathrm{a}$ & 81.90 \\
\hline & 6 hours & $44.95 \mathrm{a}$ & 7.58 & $10.96 \mathrm{a}$ & 3.65 & $14.35 \mathrm{a}$ & 2.68 & $172.5 \mathrm{a}$ & 69.10 \\
\hline & 12 hours & $43.82 \mathrm{a}$ & 5.94 & $8.54 \mathrm{a}$ & 2.83 & $7.31 \mathrm{a}$ & 3.22 & $71.7 \mathrm{a}$ & 40.70 \\
\hline & Significance test & $*$ & & NS & & NS & & NS & \\
\hline \multicolumn{10}{|c|}{ Day 2} \\
\hline \multirow{3}{*}{ Species } & Scomber scombrus & 42.12 & 9.32 & 8.73 & 3.08 & 18.73 & 3.72 & 225.1 & 72.90 \\
\hline & Trachurus trachurus & 40.84 & 5.38 & 8.01 & 2.31 & 16.97 & 3.39 & 184.5 & 67.70 \\
\hline & Significance test & NS & & NS & & NS & & NS & \\
\hline \multirow{3}{*}{ Sexe } & Female & 48.98 & 6.25 & 6.52 & 2.72 & 12.69 & 3.12 & 109.3 & 57.7 \\
\hline & Male & 40.21 & 8.93 & 8.11 & 2.76 & 18.46 & 3.52 & 213.3 & 67.7 \\
\hline & Significance test & NS & & NS & & $* * *$ & & $* *$ & \\
\hline \multirow{4}{*}{ Break duration } & 3 hours & 38.68 & 5.55 & 8.33 & 2.26 & $17.73 b$ & 3.03 & 198.7 & 64.00 \\
\hline & 6 hours & 43.73 & 5.43 & 9.41 & 2.38 & $18.82 \mathrm{a}$ & 2.94 & 228 & 68.9 \\
\hline & 12 hours & 43.2 & 8.53 & 7.39 & 2.47 & $19.96 \mathrm{ab}$ & 4.72 & 239.6 & 90.9 \\
\hline & Significance test & NS & & NS & & $*$ & & NS & \\
\hline \multicolumn{10}{|c|}{ Day 3} \\
\hline \multirow{3}{*}{ Species } & Scomber scombrus & 41.07 & 8.05 & 9.59 & 3.04 & 18.78 & 4.63 & 237.4 & 83.5 \\
\hline & Trachurus trachurus & 42.26 & 5.42 & 7.89 & 2.11 & 16.3 & 3.21 & 171.26 & 54.72 \\
\hline & Significance test & NS & & NS & & NS & & NS & \\
\hline \multirow{3}{*}{ Sexe } & Female & 51.24 & 3.98 & 6.84 & 2.68 & 14 & 3.29 & 129.4 & 56.9 \\
\hline & Male & 40.1 & 7.1 & 8.69 & 3.09 & 19.11 & 4.43 & 234.8 & 81.9 \\
\hline & Significance test & $*$ & & $*$ & & $*$ & & $*$ & \\
\hline \multirow{4}{*}{ Break duration } & 3 hours & 39.92 & 5.92 & 8.01 & 2.42 & 18.81 & 6.3 & 230 & 93.4 \\
\hline & 6 hours & 40.73 & 7.09 & 9.61 & 1.31 & 17.99 & 2.15 & 211 & 47.7 \\
\hline & 12 hours & 41.69 & 6.69 & 7.68 & 2.82 & 19.78 & 4.91 & 240 & 88 \\
\hline & Significance test & NS & & NS & & NS & & NS & \\
\hline
\end{tabular}

L*: lightness; $\mathrm{a}^{*}$ : red index; $\mathrm{b}^{*}$ : yellow index; SD: Standard deviation; NS: $\mathrm{P}>0.05 ; *$ : $\mathrm{P}<0.05 ; * *$ : $\mathrm{P}<0.01$; ***: $\mathrm{P}<0.001$; the intra-class means of the same column followed by different letters differ significantly at the threshold of $5 \%$;

Table 5 The technique effect on the freshness state of fish

\begin{tabular}{|c|c|c|c|c|c|c|c|c|c|}
\hline \multirow{3}{*}{ Variables } & \multicolumn{8}{|c|}{ Techniques } & \multirow{3}{*}{ Significance test } \\
\hline & \multicolumn{2}{|l|}{ TBF } & \multicolumn{2}{|l|}{ CBF } & \multicolumn{2}{|l|}{ CBR } & \multicolumn{2}{|l|}{ TBR } & \\
\hline & Mean & SD & Mean & SD & Mean & SD & Mean & SD & \\
\hline Skin & $2.86 \mathrm{a}$ & 0.22 & $2.96 \mathrm{a}$ & 0.10 & $2.07 \mathrm{a}$ & 0.39 & $1.70 \mathrm{a}$ & 0.59 & NS \\
\hline Eye & $1.97 \mathrm{a}$ & 0.09 & $2.06 \mathrm{a}$ & 0.20 & $2.11 \mathrm{a}$ & 0.75 & $2.08 \mathrm{a}$ & 0.62 & NS \\
\hline Gills & $2.33 \mathrm{a}$ & 0.28 & $2.36 \mathrm{a}$ & 0.23 & $2.55 \mathrm{a}$ & 0.31 & $2.59 \mathrm{a}$ & 1.29 & NS \\
\hline Back muscle & $3 a$ & 0 & $3 a$ & 0 & $2.5 \mathrm{ab}$ & 0.5 & $2.17 b$ & 1.13 & *** \\
\hline Abdominal cavity & $2.91 \mathrm{a}$ & 0.28 & $3 a$ & 0 & $3 a$ & 0 & $3 \mathrm{a}$ & 0 & NS \\
\hline Spine & $2.25 b$ & 0.39 & $2 \mathrm{c}$ & 0 & $2.50 \mathrm{a}$ & 0 & $2.32 b$ & 0.27 & $* * *$ \\
\hline Organes color & $2 b$ & 0 & $2 b$ & 0 & $2.33 \mathrm{a}$ & 0.47 & $2.31 \mathrm{a}$ & 0.54 & $* * *$ \\
\hline Peritoneum & $2 \mathrm{a}$ & 0 & $2 \mathrm{a}$ & 0 & $3 a$ & 0 & $3 a$ & 0 & NS \\
\hline Total & $24.66 \mathrm{a}$ & 0.85 & $24.75 \mathrm{a}$ & 0.47 & $25.29 \mathrm{a}$ & 2.93 & $24.12 \mathrm{a}$ & 4.54 & NS \\
\hline Mean & $2.74 \mathrm{a}$ & 0.09 & $2.75 \mathrm{a}$ & 0.05 & $2.81 \mathrm{a}$ & 0.32 & $2.68 \mathrm{a}$ & 0.5 & NS \\
\hline
\end{tabular}


Table 6 The break effect on the freshness state of fish

\begin{tabular}{|c|c|c|c|c|c|c|c|}
\hline \multirow{3}{*}{ Variables } & \multicolumn{6}{|l|}{ Break } & \multirow{3}{*}{$\begin{array}{l}\text { Significance test } \\
\text { Break }\end{array}$} \\
\hline & \multicolumn{2}{|l|}{$3 \mathbf{h}$} & \multicolumn{2}{|l|}{$6 h$} & \multicolumn{2}{|l|}{$12 \mathrm{~h}$} & \\
\hline & Mean & SD & Mean & SD & Mean & SD & \\
\hline Skin & $1.77 \mathrm{~b}$ & 0.7 & $2.57 \mathrm{a}$ & 0.29 & $1.75 b$ & 0.81 & *** \\
\hline Eye & $2.16 \mathrm{a}$ & 0.38 & $2.42 \mathrm{a}$ & 0.35 & $1.51 \mathrm{~b}$ & 0.35 & $* * *$ \\
\hline Gills & $2.73 a$ & 1.82 & $2.73 a$ & 0.23 & $2.05 \mathrm{a}$ & 0.22 & NS \\
\hline Back muscle & $2.5 \mathrm{a}$ & 0.94 & $3.00 \mathrm{a}$ & 0 & $1.69 \mathrm{~b}$ & 1.25 & $* * *$ \\
\hline Abdominal wall & $2.28 b$ & 0.46 & $3.00 \mathrm{a}$ & 0 & $2.38 b$ & 0.96 & $* * *$ \\
\hline Abdominal cavity & $3.00 \mathrm{a}$ & 0 & $3.00 \mathrm{a}$ & 0 & $2.92 \mathrm{a}$ & 0.27 & NS \\
\hline Spine & $2.57 \mathrm{a}$ & 0.18 & $2.14 \mathrm{~b}$ & 0.30 & $2.19 \mathrm{a}$ & 0.25 & $* * *$ \\
\hline Organes color & $1.92 \mathrm{~b}$ & 0.26 & $2.71 \mathrm{a}$ & 0.46 & $2.00 \mathrm{~b}$ & 0 & $* * *$ \\
\hline Peritoneum & $2.71 \mathrm{a}$ & 0.46 & $2.71 \mathrm{a}$ & 0.46 & $2.69 \mathrm{c}$ & 0.48 & $\mathrm{NS}$ \\
\hline Total & $24.32 \mathrm{a}$ & 4.29 & $27.05 \mathrm{a}$ & 1.67 & $21.25 \mathrm{~b}$ & 2.71 & $* * *$ \\
\hline Mean & $2.70 \mathrm{a}$ & 0.47 & $3.00 \mathrm{a}$ & 0.18 & $2.36 \mathrm{~b}$ & 0.30 & $* * *$ \\
\hline
\end{tabular}

SD : Standard Deviation; NS: $>0.05 ; * * *: \mathrm{P}<0.001$; The averages of the same line followed by different letters differ significantly at the threshold of $5 \%$;

\section{DISCUSSION}

Effect of species, preservation technique and break duration on the technological characteristics of fish

The difference between the whole fish weight, the various organs/parts weight (eviscerated fish, fillets and viscera), the yields and the water content of Atlantic mackerel and Horse mackerel is due to the genetic type.

Atlantic mackerel (Scomber scombrus) are generally large and fatty fish (Alinasabhematabadi, 2015) and Horse mackerel (Trachurus trachurus) have a fairly compressed elongated body with a wide head (FAO, 2018). The noted differences in the various organs and yields are due to the whole weights difference between the two species. This weight is higher in S. scombrus than in T. trachurus. The remains of both species are very important in relation with the whole weight and are a limiting factor for high fillet weights obtaining. Thus, $S$ scombrus has a higher fillet weight than T. trachurus, which explains the higher filleting yield of S. scombrus compared to T. trachurus.

In addition, morphometric parameters such as standard length, total length, body perimeter, condition factor, and body shape influence different yields (eviscerated, beheaded, and carcass). Studies on the carcass characteristics of Labeo rohita (Sahu et al., 2013) and on those of Hypselobarbus pulchellus (Raghunath et al., 2016) have shown that the fish body perimeter is a good indicator to assess yields (carcass and filleting). In the current study, the round body shape of Atlantic mackerel influenced the fillet yield compared to $T$. trachurus of which the body shape is flat. Even the Toubiana (2016) studies on the yield prediction of Dicentrarchus labrax reveal that fish with a small head have a better fillet yield. In this study, S. scombrus have a small pointed head and show a better yield than $T$. trachurus which have a wide head. Besides, the differences in fillet yield may also be related to lower trimming losses (Bugeon et al., 2008).

Alfaro et al. (2013) report for the same species a water content of $61-63 \%$ close to $71.38 \pm 10 \%$ found in the current study. In Atlantic mackerel, weights ranging from 318 to $556 \mathrm{~g}$ were reported by Fjermetad $\boldsymbol{e t}$ al. (2000) and water contents ranging from 65 to $78 \%$, by Aubourg et al. (2005). The values reported in this study are within the ranges reported by these authors. In addition, the frozen fish showed a better yield and a higher water content than the refrigerated fish; this is due to the storage temperature in both techniques because the break duration has no influence on these two variables. According to Magnussen et al. (2008), the lower is the storage temperature, the better is the yield.

The highest $\mathrm{pH}$ values were found in frozen fish because the freezing temperature is lower $\left(-18^{\circ} \mathrm{C}\right)$ than that of the refrigeration $\left(+4^{\circ} \mathrm{C}\right)$ and allows fish to better maintain their freshness state. Contrary to our study, Obemeata and Christopher (2012) didn't show this preservation technique effect (freezing and refrigeration) on the $\mathrm{pH}$ until the 2 nd week of preservation in Tilapia guineensis. Even, Akter et al. (2014) observed a pH increase in frozen Pangasianodon hypophthalmus at $-20^{\circ} \mathrm{C}$ after 100 days. Alfaro et al. (2013) reported $\mathrm{pH}$ values ranging from 6.2 to 6.9 in Atlantic mackerel (Scomber scombrus) kept at temperatures ranging from 2 to $10^{\circ} \mathrm{C}$ and present no correlation with the bacterial load growth. In addition, Aubourg et al. (2001) reported that $\mathrm{pH}$ is not a good freshness state indicator.

The influence of the break duration on the whole fish weight, the eviscerated fish weight and the remains weight is due to changes in the fish freshness state. Thus, 3 hours after the cold break, fish preserve better their states, 6 hours after, they lose water (preservation ice water in particular) and consequently lose weight; then 12 hours after the preservation, fish degradation begins and several elements are already in decomposition (denaturation) and gases take form, which increases the fish weight. In addition, during freezing, $95 \%$ of the fish composition water freezes and the ice crystals formation damages the texture and is factor favoring water and nutrients losses during freezing (FAO and OMS, 2012; Liu and al., 2013; Sampels, 2014). Water losses are obtained in Epinephelus coioides fillets stored at $+4^{\circ} \mathrm{C}$ (Sharifian et al., 2014) and in Chinese carp fillets (Ctenopharyngodon idella) stored at $-3^{\circ} \mathrm{C}$ (Liu and al., 2013). Also, weight losses were registered in salmon (Salmo salar) eviscerated and refrigerated at $+4.5^{\circ} \mathrm{C}$ on the day 0 and after two days, the weight loss stabilized at about $2 \%$ (Erikson and al., 2011). These water losses lead to pathogenic microorganisms' development or toxin formation (Moons, 2016). The break in the cold chain aggravates the water losses in the current study. However, according to Erikson and $\boldsymbol{a l}$. (2011) the weight increase of preserved fish is unacceptable from a commercial point of view.

Moreover, no influence of the break duration was noted on the $\mathrm{pH}$ which confirms the hypothesis of Aubourg and al. (2001) according to which $\mathrm{pH}$ is not a good freshness state indicator.

\section{Effect of break in the cold chain on color and freshness state}

The day of the cold break has no influence on the lightness, red index, yellow index and chroma of fish (Horse mackerel and Atlantic mackerel). The works of Hong and al. (1996) on Atlantic mackerel (Scomber scombrus) show no variation in lightness, red index, yellow index and chroma during the first experimentation week but from the 14th day, the flesh of these Atlantic mackerels kept at $-2^{\circ} \mathrm{C}$ was lighter, redder and yellower. Similarly, no difference in color $\left(\mathrm{L}^{*} ; \mathrm{a}^{*} ; \mathrm{b}^{*}\right)$ was observed in salmon fillets (Salmo salar) stored at $+4.5^{\circ}$ $\mathrm{C}$ on the experimentation day 4 , but the difference in color appears on the 11 th day (Erikson and al., 2011). The current study lasted only 3 days and doesn't show this influence.

The red index decreases with the break duration and this is characteristic of the progressive deterioration of the freshness state. Thus, fish were lighter for 3 hours of breaks than for 12 hours of breaks on the day 1. Similarly, Knockaert and $\boldsymbol{a l}$. (2007) claim that usually, a raw fresh of fish fillet has a translucent appearance. The lightness difference observed during a refrigerated storage makes the flesh to become progressively milky and opaque. This phenomenon is probably due to proteins denaturation. This denaturation has already been reported in most of the preserved fish (Bratt, 2010) and in ling-cod fillet (Ophiodon elongates) refrigerated at $2^{\circ} \mathrm{C}$ and frozen at $20^{\circ} \mathrm{C}$ (Duan and al. 2010). The freshness state of the various organs didn't vary from one species to another, and this shows that the fish were subjected to the same experimental conditions.

The dorsal muscle and abdominal wall of the frozen fish and the control batch of refrigerated fish showed a better freshness state than that of the refrigerated experimental batch and this is justified by the storage temperature of each technique. Indeed with refrigeration, the fish are kept at $+4^{\circ} \mathrm{C}$ of temperature whereas with freezing, they are kept at $-18^{\circ} \mathrm{C}$ of temperature and so, they are better preserved. This also justifies the difference in the abdominal wall that was soft in refrigerated Atlantic mackerel while intact in frozen Atlantic mackerel The influence of preservation temperature on fish freshness state in general has been reported by Duan and $\boldsymbol{a l}$. (2010) and particularly on Trachurus trachurus by Alfaro and $\boldsymbol{a l}$. (2013). During refrigeration, the cold stops or slows down the cellular activity, the enzymatic reactions and induces during the cold break water losses. The muscular structures don't toughen but soften when the temperature increases with the cold break. The temperature variation at the cold break explains the differences in the abdominal wall for each of the preservation techniques. Obemeata and Christopher (2012) also reported this effect of storage temperature on the freshness state of Tilapia guineensis. Indeed, the high temperatures accelerate the fish degradation which is on the contrary slowed down at low temperature. As a result, if the fresh fish is kept at a low temperature, the quality loss is slow. The faster the low temperature is reached during fish refrigeration, the more effectively the deterioration phenomenon is inhibited (Shawyer and Medina Pizzali, 2005). Margeirsson et al. (2010a) and Mai and al. (2012) confirm that at a temperature close to $0^{\circ} \mathrm{C}$ a high quality of freshness state is obtained. The break duration has no effect on the gills and abdominal cavity state because these organs are not superficial. In addition, the 
experimentation duration is relatively short (12 hours of break at the maximum) and didn't reveal the freshness state changes of these organs. By contrast, it influences the freshness state of the skin, eye, dorsal muscle, abdominal wall and spine which are superficial organs and therefore immediately subjected to the environment influence. Thus, immediately after death, the fish muscle is completely relaxed and the elastic and flexible texture usually lasts a few hours, after which the muscle contracts (Bouazaoui, 2011). When it toughens, the body stiffens up and the fish is then in rigor mortis state (Bouazaoui, 2011).

\section{CONCLUSION}

The impact of break in the cold chain on the technological qualities of Scomber scombrus and Trachurus trachurus shows that the weight, yield and water content of fish vary between the two species. The cold chain maintenance during freezing guarantees a better fish freshness state. Preservation by refrigeration deteriorates the fish freshness state and modifies the internal organs state (abdominal wall, spine, and organs color). The red index and the yellow index of $S$. scombrus are more affected than those of $T$. trachurus. The cold chain interruption influences the fish quality. In general beyond the 3 hours of break, the fish quality deteriorates. After 6 hours of the cold break, fish are more and redder. On the day 2 of cold break and after 6 hours of time, fish lose their sensory quality because of the flesh yellow index which is more affected.

However, fish evisceration prior preservation and continuous maintenance of the cold chain would guarantee a high quality of the preserved and consumed fish in Benin.

\section{REFERENCES}

ABUBAKAR, A., UZAIRU, A. 2015. Risk Assessment of Heavy Metals in Imported frozen fish Scomber scombrus Species Sold in Nigeria: A Case Study in Zaria Metropolis. Advances in Toxicology, Article ID 303245, 11 p.

AKTER, M., ISLAM, M. J, MIAN, S., SHIKHA F. H., RAHMAN M. H., KAMAL M. 2014. Changes in Fillet Quality of Pangas Catfish (Pangasianodon hypophthalmus) During Frozen Storage. World Journal of Fish and Marine Sciences, 6 (2): 146-155.

ALFARO, B., HERNANDEZ, I., BALINO-ZUAZO, L., BARRANCO, A. 2013 Quality changes of Atlantic horse mackerel fillets (Trachurus trachurus) packed in a modified atmosphere at different storage temperatures. Journal of the Science of Food and Agriculture, (93) 2179-2187.

ALINASABHEMATADI, L. 2015. Protein oxidation in Atlantic mackere (Scomber scombrus) during chilled and frozen storage. Thesis of Norwegian University of Science and Technologiy. $99 \mathrm{p}$.

ANSES (AGENCE NATIONALE DE SÉCURITÉ SANITAIRE). 2010. Rapport sur la consommation des poissons, mollusques et crustacés : Aspect nutritionnels et sanitaires pour l'Homme,130p. www.anses.fr. Consulté le 05/08/2018

AUBOURG, S. 2001. Damage detection in horse mackerel during chilled storage. Journal of Americain Oil Chemists' Society, (78), 857-862.

AUBOURG, S. P., RODRIGUEZ, A. \& GALLARDO, J. M. 2005. Rancidity development during frozen storage of mackerel (Scomber scombrus): effect of catching season and commercial presentation. European Journal of Lipid Science and Technology, (107), 316-323.

BUGEON, J., LEFEVRE, F., DAVENEL, A., HAFFRAY, P. 2008. Rendements de découpe et de qualité de la chair chez trois espèces de Salmonidés : la truite arc en ciel, la truite fario et le saumon atlantique. $12^{i e ̀ m e}$ édition des Sciences $d u$ Muscle et Technologies des Viandes (JSMTV), 179-180.

BOCODAHO, B.G. 2015. Etats des lieux sur les techniques de conservations par le froid des poissons d'eau marine Scomber scombrus (Maquereau commun) et Trachurus trachurus (Chinchard) dans le sud du Bénin (Abomey-Calavi et Cotonou). Rapport de fin de formation pour l'obtention de la licence en Production et Santé Animale, Ecole Polytechnique d'Abomey-Calavi, Université d'Abomey-Calavi; 48p.

BOU M'HANDI, N., AKENDENGUE, R., MAATA, N., RHARBI N. 2015 Effet de l'entreposage à l'état congelé sur la qualité de la sardine (Sardina pilchardus). Afrique Science, 11(2) 147- 160.

BOUAZZAOUI, Y. 2011. Chapitre II : Altération de la qualité des produits de la mer: technologies de transformation des produits de la mer. Altération de la qualité l'axiale de la formation spécialisée. Maroc.12p. http://fr.scribd.com/doc/46466660/Alteration-de-la-qualite-des-produits-de-lapeche. Consulté le 06/03/18.

BRATT, L. 2010. Fish Canning Handbook. Blackwell Publishing Ltd, p 322 ISBN 978-1-4051-8099-3

CODEX STAN 167-(1989). La détermination de la teneur en eau du poisson entier par la méthode de coupe transversale ; page 9-11.

CHABI, N.W., KONFO, C.T.R., EMONDE, P. D. M., CAPO CHICHI, M. T., CHABI SIKA, K. J. K., ALAMOU, Y., KEKE, M., DAHOUENON-AHOUSSI, E., BABA-MOUSSA L. S. 2014. Performance d'un dispositif amélioré de fumage (four Chorkor) sur la qualité du poisson fumé dans la commune
d'Aplahoué (Sud-Est du Bénin). International Journal of Innovation and Applied Studies, (Vol. 9) :1383-1391 p.

DEGNON, G.R., DOUGNON, T.J., TOUSSOU, S., MIGAN S.Y., 2012 Evaluation de la qualité microbiologique et physico-chimique des poissons capturés et commercialisés au port de pêche industrielle de Cotonou. Journal of Applied Biosciences, 6(1): 166-174. Available online at http://ajol.info/index.php/ijbcs.

DEGNON, R. G., AGOSSOU, V., ADJOU, E.S., DAHOUENON-AHOUSSI, E., SOUMANOU, M. M., SOHOUNHLOUE, D.C.K. 2013. Qualité microbiologique du chinchard (Trachurus trachurus) au cours du processus de fumage. Journal of Applied Biosciences (67):5210- 5218. Available online at http://ajol.info/index.php/ijbcs

DUAN, J., CHERIAN, G., ZHAO, Y.Y. 2010. Quality enhancement in fresh and frozen lingcod (Ophiodon elongates) fillets by employment of fish oil incorporated chitosan coatings. Food Chemistry, 119 524-532.

ERIKSON, U., MISIMI, E., GALLART-JORNET L. 2011. Superchilling of rested Atlantic salmon: Different chilling strategies and effects on fish and fillet quality. Food Chemistry, (127), 1427-1437.

FAO/OMS. 2012. Code d'usages pour les poisons et les produits de la pêche. Première édition, Rome, 271p ; ISBN 978-92-5-207018-4.

FAO. 2017. Fishery and aquaculture statistics, 265 p. www.fao.org/fishery/statistics/yearbook/fr ; consulté le 19/03/2018.

FAO. (2018). Species Fact Sheets-Trachurus trachurus (Linnaeus, 1758) Fisheries and aquaculture department, 4 p. Available to www.fao.org/fishery/species/2473/en consulted on 21/03/2018.

FJERMESTAD, A., HEMRE, G., HOLM, J. C., TOTLAND, G. K. FRÈYLAND, L. 2000. Effects of different dietary fat levels in cage fed Atlantic mackerel (Scomber scombrus). European Journal of Lipid Science and Technology, (102), 282-286.

GANDOTRA, R, SHARMA, S., KOUL, M., GUPTA S. 2012. Effect of Chilling and Freezing on Fish Muscle. Journal of Pharmacy and Biological Sciences (IOSRJPBS), 2(5):05-09.

GHALY, A.E., DAVE, D., BUDGE, S., BROOKS, M. 2010. Fish spoilage mechanisms and preservation techniques: review. American Journal of Applied Sciences, (7): 859-877.

GNIMAVO, E. M. 2015. Caractérisation de la chaîne du froid des poissons (Scomber scombrus et Trachurus trachurus) dans la commune d'Abomey Calavi, rapport de fin de formation pour l'obtention de la licence en Production et Santé Animale, 47p.

HONG, L. C., LEBLANC, E. L., HAWRYSH, Z. J., HARDIN, R. T. 1996. Quality of Atlantic mackerel (Scomber scombrus L.) fillets during modified atmosphere storage. Journal of food science, (61), 646-651.

ISO 7218 (2007). Microbiologie des aliments : règles générales pour les examens microbiologiques ; Troisième édition, $74 \mathrm{p}$.

KABAMBA, M. 2016. Analyse de la qualité de la chair du poisson Trachurus trachurus vendu sur les marchés de Mbujimayi. Journal of Animal et Plant Sciences 28 (2): 4450-4456.

KNOCKAERT, C., CORNET, J., CARDINAL, M., GASSET, E. MAAMAATUAIAHUTAPU, MOANA., COVES, D. 2007. Caractérisation de la qualité du Platax (Platax orbicularis) issu de l'aquaculture Document IFREMER, 88p. www.archimer.ifremer.fr/doc/00058/16917/14397.pdf

KPODEKON, M., HOUNKPÈ, E., SESSOU P., YÈHOUENOU, B. SOHOUNHLOUÉ D., FAROUGOU, S. 2014. Microbiological Quality of Smoked Mackerel (Trachurus trachurus), Sold in Abomey-Calavi Township Markets, Benin. Journal of Microbiology Research, 4(5): 175-179.

LANLAN, L., LIPING, W., TIANTIAN, W., SHIGUO, C., TIAN, D., YAQIN, H. 2017. A study of ice crystal development in hairtail samples during different freezing processes by cryosectioning versus cryosubstitution method International Journal of Refrigeration, https://doi.org/10.1016/j.ijrefrig.2017.10.014.

LIU, D., LIANG, L., XIA, W., REGENSTEIN, J. M., ZHOU, P. 2013 Biochemical and physical changes of grass carp (Ctenopharyngodon idella) fillets stored at $3^{\circ} \mathrm{C}$ and $0^{\circ} \mathrm{C}$. Food Chemistry, (140)105-114

MAGNUSSEN, O. M., HAUGLAND, A., HEMMINGSEN, A.K.T., JOHANSEN, S., NORDTVEDT, T.S. 2008. Advances in superchilling of foodProcess characteristics and product quality. Trends in Food Science \& Technology, (19) 418-424.

MAI, N. T., MARGRIRSSON, B., MARGEIRSSON, S., BOGASON, S. G. SIGURGISLADOTTIR, S., ARASON, S. 2012. Temperature mapping of fresh fish supply chains-air and sea transport. Journal of Food Process Engineering, 35(4), 622-656.

MARGEIRSSON, B., LAUZON, H. L., THORVALDSSON, L., ARNASON, S V., ARASON, S., VALTYSDOTTIR, K. L., MARTINSDOTTIR, E. 2010a Optimised Chilling Protocols for Fresh Fish. Matis. ISSN 1670-7192.

MOONS, E. 2016. Circulaire relative aux denrées alimentaires congelées, surgelées ou décongelées. Agence fédérale pour la sécurité de la chaîne alimentaire, PCCB/S3/EM/1094980, 16 pages. 
NALAN, G., PINAR, Y. 2015. Seafood chilling, refrigeration and freezing: Science and Technology. John Wiley and sons, Ltd. Published, ISBN: $1118512189,248 \mathrm{p}$.

OBEMEATA, O., CHRISTOPHER, N. 2012. Organoleptic Assessment and Proximate Analysis of Stored Tilapia guineensis. Annual Review \& Research in Biology, 2(2), 46-52.

OKPANACHI M.A., YARO C.A., BELLO O.Z. 2018. Assessment of the Effect of Processing Methods on the Proximate Composition of Trachurus trachurus (Mackerel) Sold in Anyigba Market, Kogi State. American Journal of Food Science and Technology, 6 (1) 26-32. https://doi.org/10.12691/ajfst-6-1-5

POPELKA, P., LUPTÁKOVÁ, O., MARCINĆÁK, S., NA J., MESARĆOVÁ L., NAGYOVÁ A. 2012. The effect of glaze and storage temperature on the quality of frozen mackerel fillets. Acta Veterinaria. Brno, (81) 397-402.

RAGHUNATH, M. R., SRIDHAR, N., HEMAPRASANTH, K. GANGADHAR, B., ANANDA, KUMAR B. S., RAJESH, N., UMALATA, H., HEGDE, G., JAYASANKAR, P. 2016. Carcass Characteristics of a Farmed Medium Carp, Hypselobarbus pulchellus (Day, 1878). Fishery Technology, (53) $1-7$.

Règlement (CE) n790/2005 de la Commission du 25 mai 2005, 15pages.

SAHU, B. B., SAMAL, R., MEHER, P. K., DAS, P. C., MISHRA, B., SAHU, A. K., JAYASANKAR, P. (2013). Carcass traits of different marketable sizes of rohu,Labeo rohita (Hamilton, 1822). Journal of Apply Ichthyology, 29, 673-677.

SAMPELS, S. 2014. The effects of storage and preservation technologies on the quality of fish products: a review. Journal of Food Processing and Preservation, ISSN $1745-4549,10$ pages.

SAS, 2013. SAS/STAT User's guide, vers, 9.4 Utilities, Cary, NC, USA, SAS Institute Inc.

SHARIFIAN, S., EBRAHIM, A., MORTAZAVI, M. S., MOGHADAM M. S. 2014. Effects of refrigerated storage on the microstructure and quality of Grouper (Epinephelus coioides) fillets; Journal Food Science Technology, 51(5):929-935. SHAWYER, M., \& MEDINA PIZZALI, A.F. 2005. L'utilisation de la glace sur les bateaux de pêche artisanale. Food of Agriculture Organisation, 119p, disponible sur http://www.fao.org/docrep/008/y5013f/y5013f00.htm

SIMOES, S.S. 2016. Conserver les aliments : Comment moins gaspiller ? Thèse de Doctorat en Médicine Vétérinaire de la faculté de Médecine de Créteil, 102 pages.

TOLSTOREBROV, I., EIKEVIK, T.M., BANTLE TM. 2017. Effect of low and ultra-low temperature applications during freezing and frozen storage on quality parameters for fish, International Journal of Refrigeration, p20 http://dx.doi.org/10.1016/i.ijrefrig.2015.11.003.

TOUBIANA, A. 2016. Paramètres génétiques de prédicteurs de rendement de découpe chez le bar et progrès génétiques potentiels par sélection. Mémoire de fin d'étude d'Ingénieur de l'Institut Supérieur des Sciences agronomiques, agroalimentaires, horticoles et du paysage d'Agrocampus-Ouest Rennes, 85 pages.

VARGHESE, T., MATHEW, S. 2016. Postmortem autolytic changes of iced stored banded Snakehead (Channa striata) (Bloch, 1793). International Journal of Fisheries and Aquatic Studies; 4(4): 262-267.

WABI, A.K. 2010. Assessment of microbiological and physico-chemical quality of fish mackerel "Trachurus trachurus" frozen and marketed, Master's Thesis, University of Abomey-Calavi, Benin, 